Vol.45, Special n. : pp. 87-89, September 2002

ISSN 1516-8913 Printed in Brazil

\title{
Antibody Conjugate Radioimmunotherapy of Superficial Bladder Cancer
}

\author{
Alan Perkins*; Melanie Hopper; Andrea Murray; Malcolm Frier and Mike Bishop \\ Departments of Medical Physics and Urology; University and City Hospitals; Nottingham; NG7 2UH; UK
}

\begin{abstract}
The administration of antibody conjugates for cancer therapy is now proving to be of clinical value. We are currently undertaking a programme of clinical studies using the monoclonal antibody C595 (IgG3) which reacts with the MUC1 glycoprotein antigen that is aberrantly expressed in a high proportion of bladder tumours. Radioimmunoconjugates of the C595 antibody have been produced with high radiolabelling efficiency and immunoreactivity using Tc-99m and In-111 for diagnostic imaging, and disease staging and the cytotoxic radionuclides $\mathrm{Cu}-67$ and Re-188 for therapy of superficial bladder cancer. A Phase I/II therapeutic trail involving the intravesical administration of antibody directly into the bladder has now begun.
\end{abstract}

Key words: Antibody, radioimmunotherapy, bladder cancer

\section{INTRODUCTION}

The long awaited application of tumour associated antibodies for the targeted therapy of cancer is now proving to be of clinical value. This has been especially successful in the therapy of the diffuse haematological malignancies where antibody has adequate access to antigen. The radioimmunotherapy of solid tumours remains a more challenging goal. Our work focuses on the diagnosis and treatment of bladder cancer. Our therapeutic strategy involves the direct administration of antibody into the bladder via a urinary catheter. This eliminates the problem of systemic non-specific uptake and allergic reactions (e.g. HAMA).

Bladder cancer is the fourth most common cancer in men in the United States and was responsible for over 12,000 deaths in 1999. This form of cancer typically presents as superficial disease, however $30 \%$ of patients progress to life threatening invasive disease requiring radical treatment such as cystectomy or radiotherapy. Patients with poor prognostic factors or muscle invasive disease require more radical treatment. Intravesical chemotherapy or immunotherapy is one approach, however current treatment results have been limited and there have been significant side effects. There is therefore a need for improved methods of treatment for superficial non-invasive disease. More effective local treatments would reduce the recurrence rate of superficial tumours and decrease the number of patients. Radiation is known to be an effective cytotoxic agent against bladder tumours. The targeted therapy approach using the intravesical administration of a monoclonal antibody offers a novel strategy for the treatment of superficial bladder cancer

\footnotetext{
* Author for correspondence
} 


\section{MATERIALS AND METHODS}

The monoclonal antibody C595 (IgG3) recognises the protein core of MUC1 mucin, which is expressed by the majority of bladder tumours. MUC1 is a glycoprotein present on normal urothelium that is aberrantly expressed in bladder cancer. The target epitope of the C595 antibody is the tetrameric motif Arg-Pro-Ala-Pro that is repeated many times within the MUC1 protein core. The reactivity of the C595 antibody with synthetic peptide containing this motif permits very efficient antibody purification using peptide epitope affinity chromatography, which unlike other methodologies enables recovery of only functionally active antibody. In-111 labelling was performed using a DTPA anhydride. Tc-99mC595 was produced using a reduction-mediated technique with mercaptoethanol. Therapeutic C595 conjugates have been produced in collaboration with the Paul Scherrer Institute in Switzerland using the radionuclides $\mathrm{Cu}-67$ and Re188. Cu-67 labelling was performed using a 14N4 macrocycle and Re-188 labelling has been achieved using both reduction mediated and carbonyl methodologies.

\section{RESULTS}

The In-111-DTPA-C595 conjugate was produced with a labelling efficiency of $98 \pm 1.6 \%$ and immunoreactivity of $86 \pm 7 \%$. Labelling efficiency and immunoreactivity for Tc-99m-C595 was $75 \pm 8.9 \%$ and $89 \pm 7.1 \%$ respectively. Imaging studies following intravenous injection have shown uptake in primary and metastatic tumours, (Simms et al. (2001) confirming the uptake in tumour and suggesting that immunoscintigraphy may have a valuable clinical role in staging and monitoring treatment (Fig 1).

Both $\mathrm{Cu}-67$ and Re-188 are beta emitters having therapeutic potential for the treatment of superficial tumours and both emit gamma rays of suitable energy for imaging thus allowing the assessment of tissue uptake and radiation dosimetry (Hughes et al. 2000, Murray et al. 2001). Cu-67 labelling was achieved with labelling efficiencies and immunoreactivity values of $50 \pm 10 \%$ and $87 \pm 12.5 \%$. reduction mediated labelling of Re-188 gave results of $62 \pm 25 \%$ and $70 \pm 17 \%$ respectively.

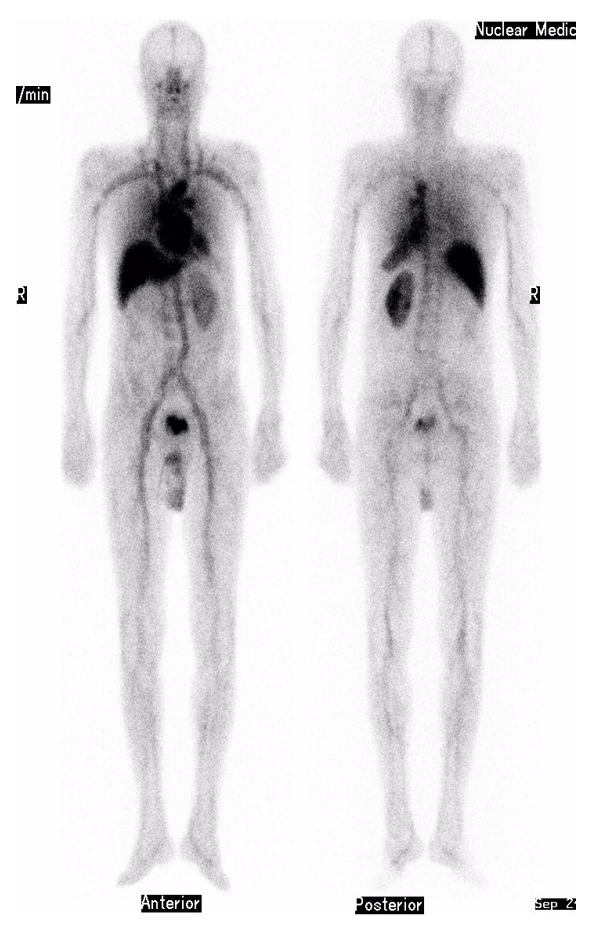

Figure 1 - Anterior (left) and posterior whole body images of a patient with a primary bladder cancer 6 hours following intravenous administration of $800 \mathrm{MBq}$ Tc-99m-C595.

Intravesical administration of tracer amounts (of the order of $20 \mathrm{MBq}$ ) have demonstrated selective uptake of these therapeutic conjugates in bladder tumours. The conjugate was administered in a volume of $50 \mathrm{ml}$ though an indwelljng urinary catherter. Two hours following the procedure the tumour-to-normal urothelium uptake of $\mathrm{Cu}-67$ C595 was 14.6:1 (n=9) and Re-188-C595 was 14.7:1 $(n=10)$. From gamma camera images the absolute retention of the tracer has been less than $5 \%$ of the administered activity.

\section{DISCUSSION AND CONCLUSION}

These studies have demonstrated the potential of this antibody for the diagnosis and therapy of bladder cancer. The intravesical approach is a novel route for radioimmunotherapy which demands further investigation. Encouraged by these initial results we have commenced a Phase I/II dose escalation study with the intravesical administration of between 0.4 and $1.0 \mathrm{GBq} \mathrm{Cu}-67-$ C595. Patients with endoscopic evidence of superficial bladder cancer will be treated and followed up for assessment of safety, 
inflammation and necrosis. These studies are intended to demonstrate proof of principle of this novel intracavitary approach for the targeted therapy of bladder cancer.

\section{RESUMO}

A administração de anticorpos conjugados para o tratamento do câncer está agora provando ser de valor clínico. Nós estamos atualmente realizando um programa de estudos clínicos usando o anticorpo monoclonal C595 (IgG3) que reage com a glicoproteína MUC1 que está aberrantemente expressa numa alta proporção de tumores de bexiga. Tem sido produzidos radioimunoconjugados do anticorpo $\mathrm{C} 595$, com alta eficiência de radiomarcação e a imunoreatividade, usando-se o Tc-99m e In-111, para o diagnóstico por imagem e estagiamento de doenças. Tem sido produzidos, também, radionuclídeos citotóxicos $(\mathrm{Cu}-67$ e $\mathrm{Re}-188)$ para o tratamento de cânceres superficiais de bexiga. A fase terapêutica I/II já se iniciou, envolvendo a administração intravesical do anticorpo diretamente na bexiga.

\section{REFERENCES}

Hughes, O. D. M.; Bishop, M. C.; Perkins, A.C.; Wastie, M. L.; Denton, G.; Price, M. R.; Frier, M.; Denley, H.; Rutherford, R. and Scubiger, P.A. (2000), Targeting superficial bladder cancer by the intravesical administration of $\mathrm{Cu}-67$-labelled antiMUC1 mucin monoclonal antibody. J. Clin. Oncol., 18, 363-370.

Murray, A.; Simms, M. S.; Scholfield, D. P.; Vincent, R. M.; Denton, G.; Bishop, M. C.; Price, M. R. and Perkins, A. C. (2001), Production and characterisation of Re-188-C595 antibody for redioimmunotherapy of transitional cell bladder cancer. J. Nucl. Med., 42, 726-732.

Simms, M.; Perkins, A. C.; Price, M. R.; Scholfield, D. P.; Bishop, M. C. (2001), Tc-99mC595 radioimmunoscintigraphy: a potential staging tool for bladder cancer. B. J. U. International., 88, 686-691. 